\title{
The Rganovo Fe-Ni Deposit: An Example of the Reworked Lateritic Weathering Crust in the Vardar Ophiolite Zone
}

\author{
T. Serafimovski ${ }^{a}$, A. V. Volkov ${ }^{b}$, B. Boev ${ }^{a}$, G. Tasev $^{a}$, \\ and Corresponding Member of the RAS A. A. Sidorov ${ }^{b}$ \\ Received March 18, 2013
}

DOI: $10.1134 / \mathrm{S} 1028334 \mathrm{X} 13090134$

The Rganovo deposit (Republic of Macedonia) is a typical representative of unique reworked lateritic $\mathrm{Fe}-$ Ni deposits in the well-known Vardar ophiolite zone of the Balkan Peninsula (Fig. 1). The Rganovo mine was developed over 30 years with brief gaps. Since the 1980 s, approximately 11.2 million tons of ores with an average nickel content of $0.92-0.94 \%$ were produced by this mine. During the last two years, ore reserves at deep levels of the deposit were thoroughly reassessed. These works were accompanied by scientific investigations, which made it possible to analyze the new geological data, study the mineralogical-geochemical properties of ores from this deposit using advanced analytical methods, and specify, based on these materials, their formation model.

Geotectonic position. The Macedonia ophiolitic complex is an integral element of the Eastern Mediterranean, which represents one of the regions with the world's highest concentrations of ophiolitic complexes. In this region, most of the Jurassic ophiolites belong to the Oman subduction-related type [1]. It should be emphasized that the Vardar zone, which represents a complex tectonic block located between the Serbian-Macedonian massif in the east and Dinarides and Helenides in the west, played the most important role in the formation and spatial displacement of Jurassic ophiolitic complexes and associated $\mathrm{Fe}-\mathrm{Ni}$ deposits in the southern Balkan Peninsula. The Vardar zone represents a belt over $1000 \mathrm{~km}$ long and $60-80 \mathrm{~km}$ wide that extends in the NW-SE direction from Belgrade through Serbia and Macedonia to the Aegean Sea in the northern part of Greece, where it subsides and turns eastward as an element of the Izmir-Ankara zone (Fig. 1).

During the Late Jurassic, opening of the basin gave way to the Vardar ocean closing that was compli-

\footnotetext{
${ }^{a}$ Joce Del'chev University, Stip, Republic of Macedonia

${ }^{b}$ Institute of Geology of Ore Deposits, Petrography, Mineralogy, and Geochemistry (IGEM), Russian Academy of Sciences, Staromonetnyi per. 35, Moscow, 119017 Russia e-mail: tma2105@mail.ru
}

cated in the east by a short subduction episode. The latter was responsible for the formation of a pelagic layer of the oceanic crust, which was accompanied by granitoid magmatism. This stage was culminated in the young Cimmerian orogenesis (collision in the late Jurassic and, largely, Early Cretaceous) with development of continental environments in the Vardar zone [2].

The Rganovo deposit is located in the Kozuf ore district near the state boundary of Macedonia and Greece (Fig. 1). This is one of the largest $\mathrm{Fe}-\mathrm{Ni}$ deposits in the Vardar Zone. With respect to its geological structure, this area is composed of Albian-Cenomanian limestones, reworked Cretaceous lateritic $\mathrm{Fe}-\mathrm{Ni}$ ores, various presumably Cretaceous shales, an ultramafic complex (serpentinites) with gabbro pegmatites and rodingites, and Tertiary volcanics.

Geological structure of the deposit. The Rganovo deposit represents several parallel thrusts composed of altered serpentinites, schists, and marbles (Fig. 2). Older tectonic (post-thrusting) movements form the radial structure. The main rocks subjected to weathering are represented by peridotites, gabbro dolerites, or serpentinites. The chemical composition of olivine, as well as the $\mathrm{Ni}-\mathrm{Fe}, \mathrm{Fe}-\mathrm{Mn}$, and $\mathrm{Ca}-\mathrm{Fe}$ correlation diagrams, allow ultramafic rocks to be attributed to "ultrametamorphites" of the Alpine type, which are identical to other ultramafics of the Balkan Peninsula [3].

The orebody morphology in the Rganovo deposit depends directly on the formation environment of this mineralization. During the deposit formation, $\mathrm{Fe}-\mathrm{Ni}$ mineralization was localized at the contact between Jurassic serpentinites and schists in the footwall of the orebody. At the same time, the orebody now occupies the typical inversion position due to intense tectonic movements at the end of the Jurassic Period: Cretaceous rocks now constitute the footwall of the orebody, while Jurassic serpentinites occur in its hanging wall. At the surface, this orebody $30-50 \mathrm{~m}$ on average extends for approximately $4 \mathrm{~km}$. The orebody is locally overlain by the thrust or, in the south, Neogene andesite tuffs. At altitudes of 955-470 m, it retains visually 


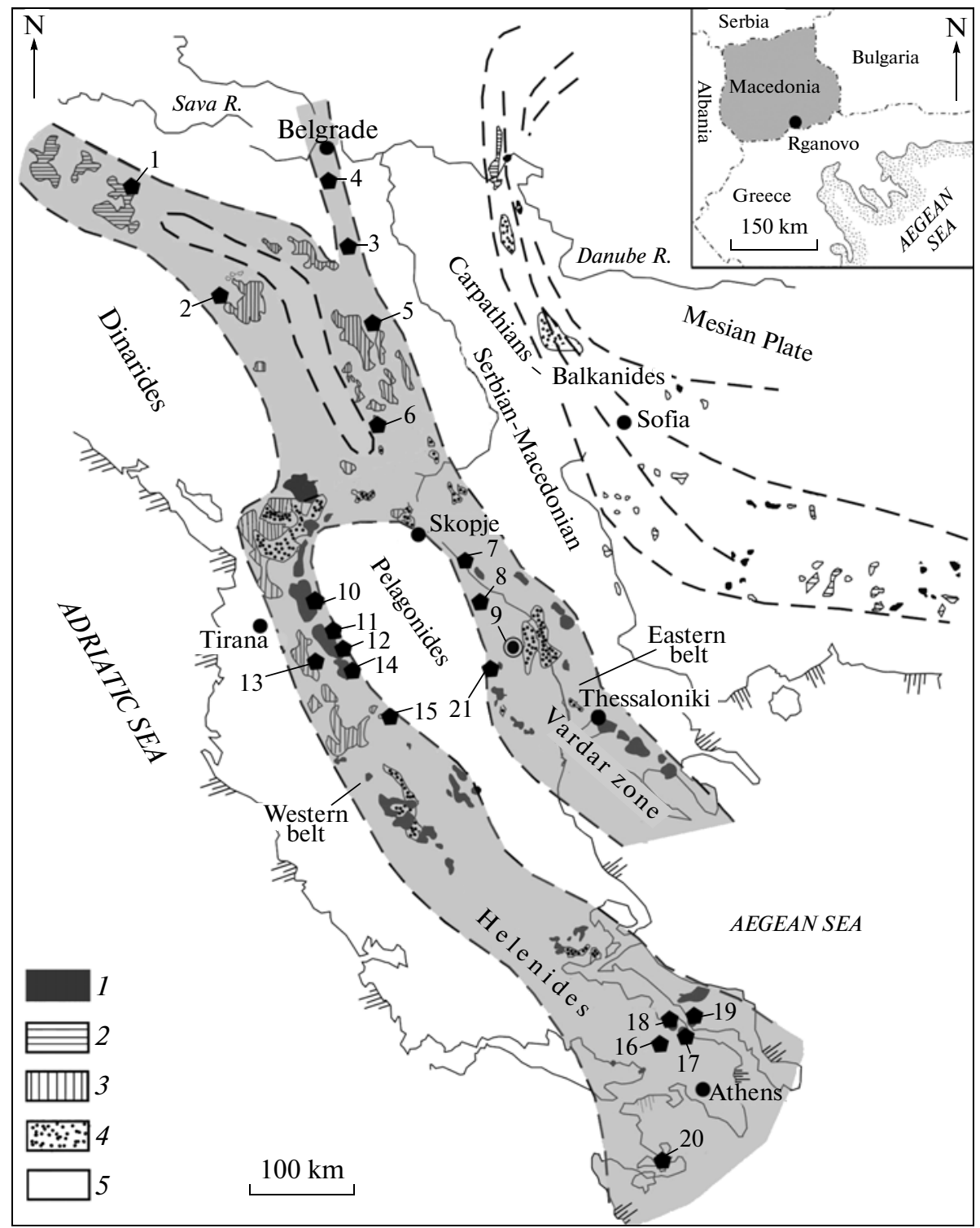

Fig. 1. Schematic location of the main deposits and ore occurrences of silicate Ni and Ni-bearing iron ore in the western and eastern parts of the ophiolitic belt in southeastern Europe [5, modified].

(1) Dunites, harzburgites; (2) harzburgites (dominant); (3) lherzolites; (4) sediments associated with pillow lavas; (5) other rocks. (1-21) deposits and ore occurrences: (1) Konzhukh (Co, Ni, Fe), (2) Mokra Gora (Fe-Ni), (3) Lipovak (Fe-Ni), (4) Ba (Ni silicate), (5) Velyuc (Ni), (6) Glogovac (Ni), (7) Glavitsa (Ni), (8) Veles Klera (Fe-Ni), (9) Rganovo (Fe-Ni), (10) Kukes (Fe-Ni), (11) Pishkash (Fe-Ni), (12) Bushtrak (Fe-Ni), (13) Gumazh (Fe-Ni), (14) Gurii Kuk (Fe-Ni), (15) Bilic (Fe-Ni), (16) Geroniya (Fe-Ni), (17) Beotiya (Fe-Ni), (18) Larumna (Fe-Ni), (19) Central Eboiya (Fe-Ni), (20) Argolis (Fe-Ni), (21) Al'mopilas ( $\mathrm{Fe}-\mathrm{Ni})$.

its thickness and occurs as a continuous curved slice despite very intense tectonics.

The orebody is composed of massive and foliated magnetite ores, oolitic foliated and massive hematite ores, riebeckite, stilpnomelane, and dolomite-talc schists, and serpentinites.

In the Rganovo deposit, foliated hematite ores with $\mathrm{Ni}$ concentrations ranging from 0.70 to $1.27 \%$ are most widespread, while their economically most significant variety is represented by massive locally devel- oped hematite ores with $\mathrm{Ni}$ contents varying from 0.93 to $1.49 \%$. The main Ni-bearing minerals are magnetite, hematite, chromite, sulfides, talc, chlorite, amphibole, and stilpnomelane.

Geological-genetic model. The formation of $\mathrm{Fe}-$ $\mathrm{Ni}$ ores in the Rganovo deposit is directly related to erosion of lateritic weathering crusts developed after Jurassic ultramafic rocks. These lateritic crusts are now represented by relicts in serpentinites. The detailed investigation of weathering lateritic crusts and 


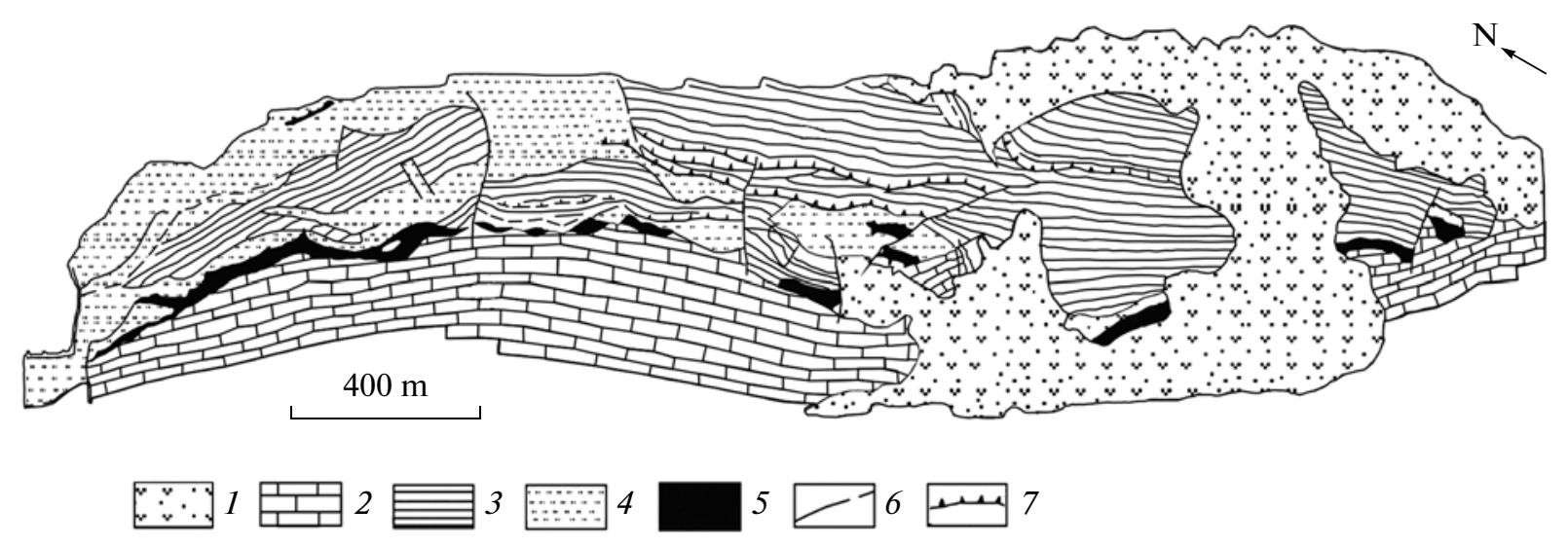

Fig. 2. Geological map of the Rganovo $\mathrm{Fe}-\mathrm{Ni}$ deposit.

(1) Tertiary volcanics and pyroclastic rocks; (2) Albian-Cenomanian limestones; (3) Cretaceous (?) shales; (4) serpentinites with gabbroid pegmatites and rodingites; (5) Cretaceous lateritic Fe-Ni ores; (6) faults; (7) thrusts.
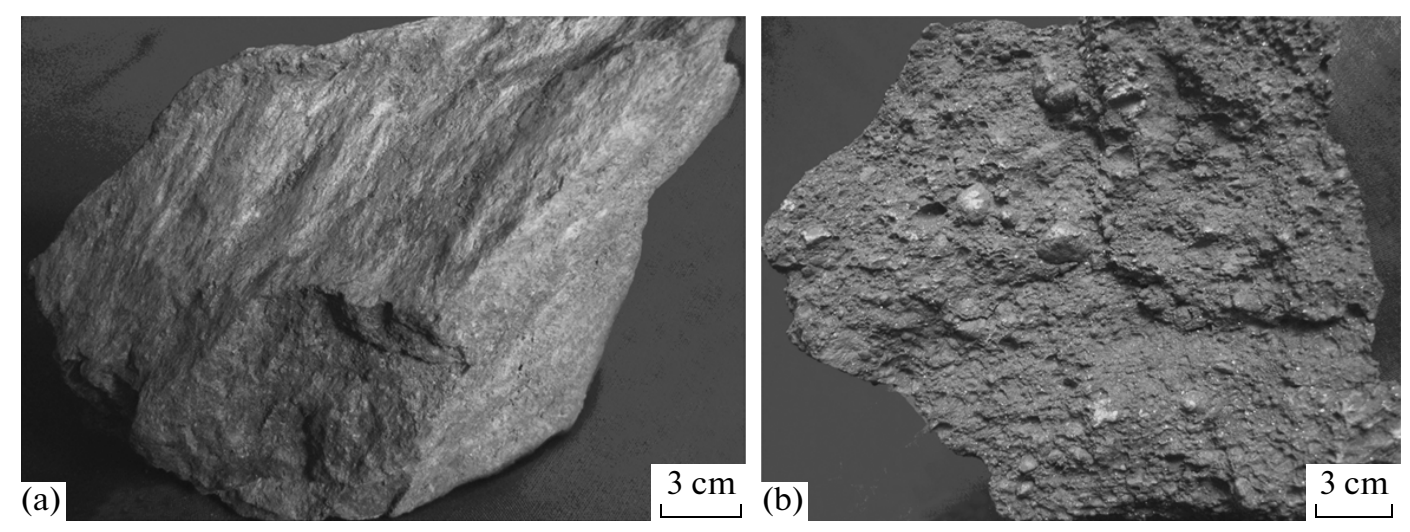

Fig. 3. Main types of ores from the Rganovo deposits. (a) Foliated hematite ores; (b) oolitic hematite ores. comparison with other $\mathrm{Fe}-\mathrm{Ni}$ deposits in the Vardar zone shows that the Rganovo deposit is lacking detrital sediments. Consequently, the sediments in the last deposit and surrounding areas were deposited in stable environments without the influx of coarse detrital material [4]. In this connection, the chemical composition of the initially formed lateritic sediments remained unchanged during reworking by mechanical and chemical processes. Stable chromites, most petrogenic minerals, and limonite were subjected to mechanical reworking, while sulfide minerals were deposited by chemical processes. Separation of $\mathrm{Fe}-\mathrm{Ni}$ minerals was closely connected with changes in the oxidation-reduction potential and the $\mathrm{pH}$ value in seawater.

It should be emphasized that most $\mathrm{Fe}-\mathrm{Ni}$ ore minerals (hematite, magnetite, limonite, pyrite, and others) are of sedimentary origin, which is evident from the development of oolitic textures of ores, when separate ooids of these minerals are observable (Fig. 3b). The presence or absence of pisolitic-oolitic products in different parts of the orebody in the Rganovo deposit indicates that the bottom patterns in the sea basin during the formation of lateritic ores were determined by its depths: the shallow sea was favorable for the formation of oolites and pisolites due to highenergy hydrodynamics, while relatively calmer deepsea environments stimulated accumulation of lithologically massive ores. The investigation of oolites revealed that their central parts are usually represented by magnetite enveloped successively by maghemite, hematite, and other minerals (Fig. 4). It should be noted that $\mathrm{Si}$ dioxide was deposited as jasper or an admixture in size-variable isolated lenses within ore layers. These jaspers are almost always slightly enriched with $\mathrm{Ni}(0.4 \%)$, which clearly indicates that their material is reworked from the lateritic weathering crust.

The lateritization and formation of typical lateritic weathering crusts of the nontronite type was in progress in the Balkan Peninsula from the Early Cretaceous until the Albian. Erosion of the nontronite 

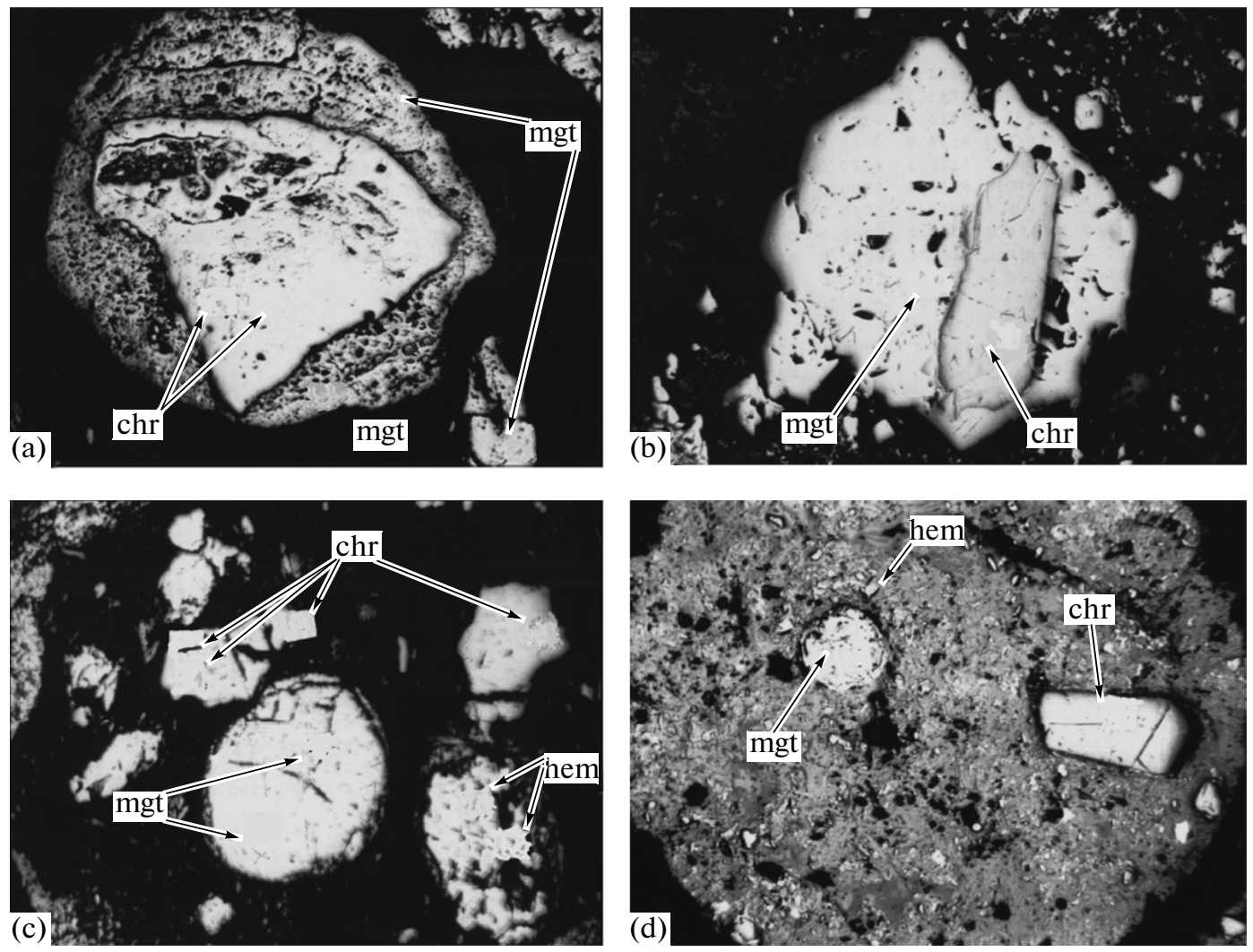

Fig. 4. Microimages of characteristic forms of main ore minerals in oolitic ores from the Rganovo Fe $-\mathrm{Ni}$ deposit. Magn. $\times 200$ (reflected light).

(a, b) Chromite inclusions in central parts of magnetite oolites; (c, d) oolitic form of magnetite grains lacking chromite inclusions. (mgt) Magnetite; (chr) chromite; (hem) hematite.

crust and material transportation to sedimentary basins occurred prior to deposition of Albian-Cenomanian limestones. It should be noted that the influx of material from primary lateritic weathering crusts was discontinuous with periods when the basin received a large share of non-lateritic material from surrounding provenances. This explains the elevated concentrations of trace elements originating from other, not ultramafic rocks in some samples. Such a process was responsible for the local low Ni concentrations in ore-bearing sediments.

The Albian-Cenomanian epoch was marked by accumulation of carbonate sediments and digenesis of the entire reworked material. These diagenetic and epigenetic transformations were accompanied by alteration of primary minerals and formation of their new varieties (for example, hematite, magnetite, millerite, pyrite, chlorite, and mixed-layer minerals formed instead of clays). The host sediments were enriched with $\mathrm{Ni}$, which originated from the weathering crust in the form of Ni hydrocarbonate.

In the terminal Late Cretaceous, the initially horizontal ore body was overturned in response to intense Alpine tectonic movements and folding: now, it occupies the subvertical position. Simultaneously, the
Rganovo deposit was subjected to dynamometamorphism: sedimentary rocks were transformed into lowtemperature metamorphites with the following mineral association: magnetite, hematite, stilpnomelane, chlorite, talc, magnesioriebeckite, albite, calcite, and dolomite [5].

Conclusions. The data presented on the Rganovo deposit show that ores that form the Ni mineralresource base form an autonomous group of deposits represented by metamorphosed reworked $\mathrm{Fe}-\mathrm{Ni}$ lateritic crusts in addition to their endogenic $\mathrm{Cu}-\mathrm{Ni}$ type associated with deep ultramafic and basic rocks and the exogenic Ni silicate type within weathering crusts developed after serpentinites. The proposed geological-genetic model allows the assumption that ore lodes in such deposits could be formed due to reworking and subsequent metamorphism of rocks locally enriched with $\mathrm{Ni}, \mathrm{Cr}$, and $\mathrm{Co}$. The distribution of platinum group elements, gold, and silver in reworked $\mathrm{Fe}-$ $\mathrm{Ni}$ deposits is of practical interest; information on the elevated contents of these elements in silicate deposits is available from domestic and foreign works published during the last 15 years [6]. 
No analogs of the Rganovo deposits have been revealed until recently in ophiolitic belts of Russia and CIS countries. At the same time, a geodynamic and metallogenic situation similar to that in the Balkan Peninsula existed in the South Urals, central Kazakhstan, the eastern Eurasian continent, and the Caucasus as well.

The presented data allow the conclusion that reworked lateritic $\mathrm{Fe}-\mathrm{Ni}$ deposits are undoubtedly controlled by ophiolitic belts. Consequently, the ophiolitic complexes known in Russia (Urals, Eastern Sayan, Caucasus, Koryak-Kamchatka, and other regions) should be reviewed with respect to their prospects for discovery of such deposits.

The Ni market conditions seem to be very favorable in the future in connection with the growing consumption of this metal in countries of the AsianPacific region (primarily in China and India), Europe, and the CIS. Therefore, the commercial interest in Ni deposits of different types should undoubtedly increase in the future.

\section{ACKNOWLEDGMENTS}

This work was supported by the Russian Foundation for Basic Research, project nos. 11-05-00006-a and 12-05-00443-a.

\section{REFERENCES}

1. H. F. Robertson, Mem. Geol. Soc. London 32, 235261 (2006).

2. H. F. Robertson, S. Karamata, and K. Saic, Lithos 108 (1/4), 1-36 (2009).

3. T. Ivanov, Proc. III Congress of Geologists of Yugoslavia. Budva (Nauka i Drustvo, Belgrade, 1962), vol. 2, pp. 249-264.

4. Z. Maksimovic, Bull. Serb. Aad. Sci. Nat. Math., No. 21, 13-26 (1981).

5. B. Boev and S. Ivankovic, Univ. "St. Cyril and Methodius," Faculty of Mining and Geology, Stip. Spec. Iss., No. 3, 270-278 (1996).

6. I. V. Talovina, Geochemistry of Uralian Oxide-Silicate Ni Deposits (NMSU “Gornyi,” St. Petersburg, 2012) [in Russian].

Translated by I. Basov 